\title{
IN FORTHCOMING ISSUES
}

James Millar, "The Little Deal: Brezhnev's Contribution to Acquisitive Socialism"

Albert Resis, "Russophobia and the 'Testament' of Peter the Great, 1812-1980"

Elizabeth K. Valkenier, "The Rise and Fall of Marxist

Historiography"

\section{TO THOSE WISHING TO SUBMIT MANUSCRIPTS}

Manuscripts for consideration should be submitted in four double-spaced copies. Footnotes should be double-spaced and placed at the end of the manuscript. Manuscripts are sent to referees anonymously and should be prepared accordingly. Library of Congress transliteration should be used. In general, articles should not exceed twenty-five pages. Manuscripts will not be returned unless postage is provided.

The policy of the Slavic Review is not to consider materials that have been published or that are being considered for publication elsewhere.

Publication of articles in the Slavic Review is ordinarily limited to those submitted by members of the AAASS. Nonmembers wishing to submit manuscripts are asked to request a membership application. 


\section{Russian at Middlebury}

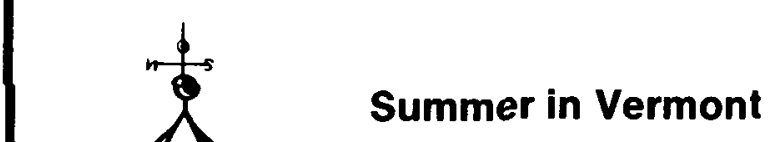

A total "all Russian" atmosphere is created on campus for language study from beginning to advanced levels, as well as graduate and postgraduate programs.

New at Middlebury in 1986: Teaching for Proficiency a five-week summer institute for teachers and future teachers of Russian. General lectures on the concept of proficiency followed by Russian language sessions in curriculum design, classroom strategies and development of materials.

\section{Academic Year in the Soviet Union}

During the academic year, undergraduates study for one semester and graduates for the full year at the Middlebury program at the Pushkin Institute in Moscow. 